HARDBOILED ZEN: JANWILLEM VAN DE WETERING'S THE

JAPANESE CORPSE AS BUDDHIST LITERATURE

Ben Van Overmeire 


\title{
HARDBOILED ZEN: JANWILLEM VAN DE WETERING'S THE JAPANESE CORPSE AS BUDDHIST LITERATURE
}

\author{
Though many studies of contemporary Buddhist literature exist, such studies often limit \\ their purview to canonised, 'high-brow' authors. In this article, I read Janwillem van de \\ Wetering's The Japanese Corpse, a detective novel, for how it portrays Zen Buddhism. I \\ show that The Japanese Corpse portrays Zen as non-dualist and amoral: good and bad \\ are arbitrary categories that impede spiritual freedom. Likewise, characters' identities \\ are fluid, not fixed. The novel shows this by insistently associating Zen with sex and \\ violence, and by the use of dramatic motifs. However, the novel also excludes women, \\ particularly Japanese women, from spiritual attainment, instead essentializing them as \\ the sexual objects of the hardboiled detective story. As a matrix of conflicting values, The \\ Japanese Corpse thus turns out to be a case study of Buddhist modernism, and of \\ challenges of detective fiction as world literature.
}

Keywords: Zen Buddhism; Janwillem van de Wetering; detective fiction; Buddhist modernism

\section{Introduction}

Transnational detective fiction is hot. The global Anglophone fiction market has developed a serious appetite for translated fiction from Scandinavia and Latin-America. Addressing this popularity, David Schmid speculates that it is the foreign backdrops of such novels that appeal to North-American audiences, a significant part of the global consumer market of detective novels (Nilsson, Damrosch, and Haen 2017, 19-20). Paired with this commercial success is a renewed academic interest in detective fiction as a global genre. Recent years have seen several investigations in this sense, applying the label 'world literature' to detective fiction.

This interest is not unjustified, as Louise Nilsson, David Damrosch, and Theo d'Haen point out, there is an urgent need to closely examine how detective fiction portrays the 'others' of western patriarchy: persons belonging to locales other than America and Europe, and women. Nillson et al. also assert that studying detective fiction 
also allows us to explore non-canonical fiction as world literature: all too often this field has focused exclusively on Dostoievsky, T.S. Eliot and the like, while virtually ignoring the global dissemination of popular fiction.(Nilsson, Damrosch, and Haen 2017, 3-4)

This tendency of literary studies to overly focus on canonised authors also shows in scholarship on modern Buddhist literature: while there is a good amount of scholarship on the Buddhist aspects of the poetry of Gary Snyder and the prose of Jack Kerouac, very little attention has been given to how Zen is portrayed in 'low-brow' genres such as science fiction or detective fiction. Yet if we are to understand how understandings of Zen have been disseminated, with the term currently being applied to anything from couches to sex manuals, we need to take seriously the power of popular fiction and its influence.

The detective fiction of Janwillem van de Wetering provides a useful starting point for an examination of both popular imaginations of Zen and the possibilities of detective fiction as 'world literature.' Taking The Japanese Corpse as a case study, I argue that Van de Wetering portrays a Zen Buddhism focused on a non-dual state of mind that allows for the acceptance of violence and sex as expressions of Buddhist emptiness. Thus, police detectives can be Zen Buddhists, and Zen monks can patronise brothels. For Van de Wetering then, Zen is fundamentally amoral. This insight and the fluid concept of identity that accompanies it is not extended, however, to Japanese women, who are never anything but inferior objects to be exploited, mostly for sex. This ambiguity of the novel - anyone can be anyone, except for Japanese women, who can only be Japanese women-demonstrates the complex process of cultural negotiation that David McMahan has called 'Buddhist modernism.' As a Buddhist modernist novel, The Japanese Corpse attempts to reconcile the generic conventions of the hardboiled detective novel with a Zen perspective. Thus, the novel draws attention to the problems and possibilities of transnational Buddhist and detective literature.

\section{Van De Wetering}

When Janwillem van de Wetering died in 2008, the obituary in The Guardian called him a 'crime novelist,' who after a long period of wandering wrote a series of bestselling thrillers, published in English and Dutch at first, but translated in many more 
languages, several movies (one featuring Rutger Hauer) and a TV-series_(Verstappen

1979, 1987; Jauch 1999; Grijpstra \& de Gier 2004). The fact that an English newspaper like The Guardian reported this news demonstrates the international popularity of this Dutch writer's so-called 'Amsterdam Cops.' In that obituary, Christopher Hawtree praises among other things the ambiguity of these crime novels, which possess both earthly and spiritual dimensions, and concludes: 'Rarely have the fictional world-weary shown such brio' (Hawtree 2008). Hawtree's comment on 'spirituality' here points us to another dimension of Van de Wetering's career: his lifelong engagement with Zen Buddhism, about which he wrote a 'Zen trilogy:' three memoirs of his time spent in various monastic environments in Japan and the United States (Van de Wetering 1971, 1974b, 1974a, 1975, 1999, 2007). Indeed, Van de Wetering was a Zen pioneer of sorts when he knocked on the temple doors of Daitokuji in Kyoto in 1958, sharing the temple space with none other than Gary Snyder (Snyder and McLean 1980, 178).

In view of this background, it should come as no surprise that Van de Wetering did not limit his discussion of Zen Buddhism to his memoirs. Indeed, a brief look at the titles of two novels, The Japanese Corpse and Inspector Saito's Small Satori, already indicates that this is the case. Yet thus far, despite their popularity and thus obvious importance to popular imaginations of Zen, these novels have not been the subject of serious scholarly attention. Focusing on The Japanese Corpse here (Inspector Saito merits its own study), I will show that this lack of attention is unwarranted, as this novel is a particularly interesting case study of how the representation of Zen is adjusted to the requirements of a specific genre, in this case the hard-boiled detective novel.

\section{Zen, Sex, and Violence}

The central event of The Japanese Corpse is the murder of a Japanese art collector in Amsterdam. The heroes of almost all Van de Wetering's detective novels, an older man called Grijpstra and his younger colleague De Gier, are tasked with investigating this murder. They soon discover that the victim is connected to the infamous yakuza, for whom he sells stolen art objects. With the purpose of rolling up this crime ring, de Gier and his boss, the unnamed 'commissaris,' (the police commissioner) travel to Japan, pose as art dealers, and try to get the attention of the yakuza boss, called 
the 'daimyo.' In this quest they are aided by Dorin, a Japanese special service agent who has lived in America. After a series of intricate maneuvers, they manage to win the daimyo's trust, after which they arrest him and his cronies with the help of Japanese special forces. But the daimyo does not want to go to prison and instead chooses to die by provoking the soldiers into shooting him. Meanwhile, in Holland, Grijpstra discovers that the murderer is a jealous ex-lover of the victim's beautiful fiancé.

Van de Wetering sprinkles the novel with Zen references. The first of these references deserves our attention, as it represents Van de Wetering's particular perspective on Zen, a perspective that can not only be found in his detective novels but also in his "Zen Trilogy." The reference itself seems innocent enough: the license plate number of the dead person is '66-33 MU' (Van de Wetering 1977, 5). 'Mu,' (Chinese: wu 無) which literally means 'no' or 'there is not' in classical Chinese, here refers to the celebrated answer Zen master Jōshū (Chinese: Zhaozhou) gave to the question of whether a dog has Buddha-nature. This so-called 'koan' riddle is often the first one students of Zen within the Japanese Rinzai school are challenged to solve. In fact, it was the first one that the young Van de Wetering was faced with during his year-long stay in the Daitokuji temple in Kyoto, an experience described in The Empty Mirror. In Afterzen, published much later, Van de Wetering comments on the koan as follows

Nothing matters. There is no tomorrow, yesterday didn't occur. Whoever gets this basic truth can sit at the side of the road, like the Chinese 'laughing Buddha,' often shown in restaurants as a fat happy figure, and be amused while a war rages right in front of his eyes, while children starve and dogs are beaten. (Van de Wetering 1999, 50)

Van de Wetering's gloss here connects the Zen idea that nothing matters with an attitude of indifference towards violence. Returning to The Japanese Corpse, it is no coincidence that the $M u$ koan appears exactly on the license plate of the car previously owned by the eponymous corpse. As we will see, in The Japanese Corpse Zen is often connected to violence.

The $M u$ - koan, or rather its famous interlocutor Jōshū, also points us to another important aspect of Van de Wetering's treatment of Zen in The Japanese Corpse, and that is sexual intercourse. Shortly after his gloss on the $M u$-koan in Afterzen, Van de Wetering discusses another koan featuring Jōshū, in which the Zen master claims to have

Deleted: particular
Deleted: the
Deleted: Van de Wetering has
Deleted: autobiographical books

Deleted: Joshu

Deleted: ' $M u$ '
Deleted: Joshu
Dormatted: Font: Italic
Deleted: Joshu


'penetrated' a wise old woman standing by the side of the road. Both Van de Wetering's teacher and his fellow monks in Japan insist that the meaning here is sexually ambiguous. As Han-San, another monk, says, Jōshū often engaged in 'pam-pam, with some old mountain lady — the old boy just loved it' (Van de Wetering 1999, 56).

At the outset of The Japanese Corpse then, the $M u$-koan signals that violence and sex will be very important in the novel's depiction of Zen. As we have already seen, we find 'Mu' on the license plate of a dead man murdered out of sexual desire. There are many more examples. Indeed, whenever a character talks about Zen, sex and violence are never far away. Discussing Zen meditation with a Yuiko, a prostitute working for the yakuza, detective De Gier receives the following response:

The girl mockingly imitated the Buddha posture, pulling up her legs and twisting them into each other and straightening her back. She closed her eyes and pouted. De Gier admired her legs; he could see her thighs and tightly stretched slip. Her pubic hair shone through the nylon. (Van de Wetering 1977, 171)

This sexualization of Zen is repeated when the undercover detectives offer a beer to a priest associated with a temple called 'Daidharmaji, ${ }^{1}$ he replies: 'Please, last few nights I drink many beers, very nice. Also gamble and meet prostitutes. Very strange occupation for priest, High Priests say this is spiritual exercise' (Van de Wetering 1977, 119).

The most important example of this combination of Zen with violence and sex involve De Gier, whose psychological experiences Van de Wetering frames within Zenlike discourse. At the beginning of the novel, De Gier has settled down with a girlfriend whom he intends to marry. It is a shock to him, then, that upon coming home, he discovers both his girlfriend and beloved cat have died in a horrible traffic accident. After this incident, De Gier is delirious and violent:

He had whined and groaned and thrown himself about in the bed, tearing at the sheets and the pillow. It had been the beginning of the rage which would later attack three Japanese hoodlums, three bad men killing a cat in a dark alley. (Van de Wetering 1977, 90).

In the above quotation, the commissaris is speaking, and he goes on to express his shock at seeing this anger in his subordinate.
Deleted: Joshu

Deleted: ' $M u^{\prime}$
Deleted:
Formatted: Font: Italic


De Gier has not only become more violent: he has also become liberated. Listening to him fall asleep almost instantly after lying down, the commissaris calls De Gier

a free man, shocked out of having to carry the weight of his own identity. He had felt the sergeant's freedom the moment de Gier had come running out of the inn to open the door of Dorin's car and to shake the commissaris' hand. But it's dangerous to be free, to stop caring. (Van de Wetering 1977, 93).

Apart from the 'danger' of attempting to murder the three cat-abusers, the commissaris' Deleted: two comment anticipates De Gier's interactions with the yakuza daimyo and his underlings. Unlike the commissaris, De Gier is not intimidated by the elaborate ploys of the daimyo. The details of these ploys deserve our attention, as they demonstrate the extent of De Gier's liberation.

The commissaris is the first one to undergo these terrifying-yet-playful machinations. Walking around the city, he makes the acquaintance of a Japanese student interested in improving his English. This student leads him to a beautiful temple in a part of the city he is unfamiliar with. In the garden, the student shows the commissaris a temple guardian, 'a ferocious statue, a snarling warrior standing on a dead body. "Dead body is self," the student had explained. "Warrior is discipline"” (Van de Wetering 1977, 131). After saying this, the student suddenly disappears, leaving the commissaris alone with the statue. After looking at it for a little while longer, he discovers that the dead body is his own: a wooden, painted mask, mimicking his features exactly, was put over the original face (see Figure 1 for an illustration of this scene). As he tells De Gier, this experience made him more afraid than the Gestapo when they threatened to pull out his toe nails (Van de Wetering 1977, 136).

Like the commissaris, De Gier also meets a Japanese 'student' while strolling through Kyoto. This student takes him to a popular theater. After seeing two unremarkable plays, De Gier is shown a piece where four people kill his mirror image, portrayed by a Japanese actor perfectly imitating his quirks. Unlike the commissaris, though, De Gier is not intimidated by this. When the lights turn back on, he takes out his flute and repeats the tragic melody that, in the play, accompanied his own death. To the 
commissaris, who does not understand his courage, De Gier explains his state of mind as follows:

They [the $y a k u z a]$ would've scared me too, under normal circumstances, I mean. But there has been the accident. [...] This must be the aftereffect of the shock; maybe I feel I have nothing to lose anymore. It's a dangerous mood to be in, asocial I think. I almost killed those fellows in Tokyo [who were torturing a cat] without any hesitation, I meant to kill them and if Dorin hadn't been around, I would have killed them. Not caring is abnormal. A normal man cares. (Van de Wetering 1977, 136)

Here, again, we find the idea of liberation closely tied to that of violence. At the same time, the motif of the dramatic performance here hints at the ultimate lack of identity, the idea that everyone is just playing a role.

De Gier later comments explicitly on the emptiness of identity, this time comparing it to a dream. When Yuiko, whom he knows to be a pawn of the daimyo, takes him on a boating trip to an island where he hopes to find the daimyo, the narrator describes De Gier's feelings as follows:

nothing matters. A very strong feeling blotting out all other sensations. [...] 'I was a

balloon,' he said aloud and turned toward the lake. A balloon, a small round bloated toy, floating about thinking it had a life and an identity of its own, until something made it pop. [...] I move, he thought, and I talk and I listen and dress and undress and shave and I drive a sports car and sail a boat and maybe I'll sleep with his girl before the day is over and if the daimyo's way of playing chess differs from what I am anticipating, I may get killed today too. I dream and the daimyo dreams and our dreams touch today, but nothing is happening. I am not taking part, I have nothing to take part with. (Van de Wetering 1977, 220)

An obvious interpretation of this scene is as the Buddhist Mahayana concept of śūnyatā, which is often translated as 'emptiness' but has more the sense of something hollow: in our world, forms are visible yes, but there is no substance to them. They are like a balloon, seemingly solid but without anything inside them.

However, Van de Wetering does more than connect De Gier's experience with śūnyatā. He also references Yoshikawa Eiji's 1930s historical novel Musashi, thereby strengthening the connection Zen-violence-sex. An exceedingly popular novel in Japan
Formatted: Font: Italic 
and abroad, Musashi fictionalises the life of Japan's most famous samurai. On his way to an island to confront his archrival like De Gier, Musashi

was thinking of nothing at all. He was, if anything, a little bored.

He looked over the side of the boat at the swirling blue water. It was deep here, infinitely deep, and alive with what seemed to be eternal life. But water had no fixed, determined

form. Was it not because man had a fixed, determined form that he cannot possess eternal life? Does not true life begin only when tangible form has been lost?

To Musashi's eyes, life and death seemed like so much froth.(Yoshikawa 1995, 964)

Yoshikawa's description of Musashi's mindset here is very similar to Van de Wetering's description of De Gier's psychological state. Both describe a warrior who does not fear death because he has seen through the emptiness of all things, including life and death. Yoshikawa's book played an important role in the popular dissemination of the image of samurai as Zen Buddhists and in the Japanese war effort: if life and death are 'so much froth,' dying in battle becomes a matter of indifference (Van Overmeire 2016).

Another similarity between Yoshikawa's Musashi and De Gier is that both these characters have sex with prostitutes at important junctures of the narrative. In the Dutch version of Afterzen, Van de Wetering remembers a scene from Musashi while burning cedarwood 'because in the novel this is burned by the most expensive rental lady of Japan when she receives Musashi in her boudoir for free' (Van de Wetering 2007, 187). ${ }^{2}$ Van de Wetering is here referring to a scene that takes place just before Musashi slaughters two of his most feared opponents. Likewise, De Gier has sexual intercourse with Yuiko just before meeting his most feared opponent, the daimyo. Moreover, while having sex De Gier continually thinks about bodies, corpses, and his own death. At the time of orgasm, his body and Yuiko's 'fuse' with 'everything, with nothing excepted' (Van de Wetering 1977, 224). The resemblances between De Gier and Musashi suggest that we can see De Gier as a modern-day Musashi. The trauma of losing his girlfriend and cat might have destroyed his ego, but he is still a warrior capable of violence and sexual relationships, only he is detached from these activities.

Like De Gier, the case of the 'villain' of the Japanese Corpse, the daimyo, demonstrates the novel's connection of Zen with sex and violence, and the idea that identity is ultimately empty. The daimyo's connection with violence should be obvious: he is the head of a criminal organization that does not hesitate to use any means necessary 
VAN OVERMEIRE 10

for profit. He also runs brothels, and apart from Yuiko, he pays for the services of a "Miss Ahboombah," an African-American stripper whose performance deeply moves both the commissaris and De Gier.

Despite his ruthless behavior, the daimyo is also a man of Zen. He abides by 'jingi’ (仁義; Van de Wetering stresses the characters with the inclusion of what is very likely his personal calligraphy; see Figure 2). Although 'jin-gi' also refers to the yakuza code of honor, the daimyo interprets these terms in a manner compatible with Zen: in the yakuza, 'two men will only be able to really meet after they have learned to destroy their own desires' (Van de Wetering 1977, 259). When the commissaris asks the daimyo directly whether he is a Buddhist, he gets the following answer:

'Would I be a Buddhist?' the daimyo said, and held his broad hands upside down in front of his chest. ' What would I be? A good question. I have no answer. My mind is clouded by the countless thoughts with which I have identified myself and which have all left their traces, and it is said that the Buddha mind is empty, empty and pure, for emptiness is always pure.' (Van de Wetering 1977, 257)

Like De Gier, the daimyo is also just playing a role, going through the motions, an idea that Van de Wetering reinforces with a scene where the daimyo acts in a Noh-play depicting his own life, and ends up being stabbed to death. Detectives and criminals turn out to be doppelgangers, two faces of the same coin, different roles in an ongoing play.

The daimyo's detachment leads the commissaris to admire him, and to question whether this criminal mastermind is really all that 'bad.' Rejecting Dorin's description of the yakuza as 'filth,' he calls the daimyo 'extraordinary,' going on to speculate that Japanese society needs people such as him, and that labels such as good and bad are contingent judgments, not absolutes (Van de Wetering 1977, 264). Earlier, Dorin himself had speculated on the relativity of moral judgements. Having spent three months in a Zen monastery as part of his military training, he praises Zen masters because they never moralize... They don't talk at you from an outside point of view, tell you what is good and what isn't. I was never impressed by morals myself, maybe because I grew up in America, but was taken to Japan all the time by my parents. I lived in two worlds, and what was good in the one was bad in the other. In Japan it is proper to burp after a meal; in America you get slapped if you do it. (Van de Wetering 1977, 105) 
Dorin's cultural relativism here is rather facile, confusing cultural convention with ethical standards. But like the cases of the daimyo and De Gier, it serves to stress a dominant message in the book: Zen is not about moral judgment, but rather about the suspension of judgement.

Thus, in The Japanese Corpse, Van de Wetering's depiction of Zen has two main, interrelated characteristics. First, he consistently associates Zen with violence and sex. Second, he depicts Zen characters, mainly De Gier and the daimyo, that do not fall into easy categories such as 'bad guy and 'good guy.' Thus, Zen in The Japanese Corpse refers to an Asian-flavored experience of non-dualism: one cannot fence off Zen and associate it with one type of person or behavior only. It can be practiced by anyone doing anything and has no moral prerequisites: it is as accessible to a war criminal torturing his victims as it is to a monk meditating in the mountains. The key is to take the ego out of whatever one is doing an idea symbolically expressed by the fierce temple statue crushing the self (cf. supra).

For Van de Wetering, dismissing morality in favor of non-dual detachment and insight solved a pressing existential problem, the problem that in the 1950s sent him across the world to a Zen temple: how could it be that his Jewish classmates were deported without mercy, and why were innocent German civilians burned in the flames of the Dresden bombings (Van de Wetering 1999, 32)? In detective novels like The Japanese Corpse, Van de Wetering proposes a solution of sorts: suffering and joy are inseparable, and violence and sexuality are as much Zen as sitting in meditation.

This vision of Zen is not without precedent in Japanese literature. As mentioned above, Yoshikawa's Musashi destroys his ego to become better at killing, an idea that reflects the so-called bushido, a warrior ethic the Japanese military created at the beginning of the twentieth century (Benesch 2014). But the idea has roots in premodern Zen as well. In a medieval treatise on the art of swordsmanship, written by the Japanese Zen abbot Takuan Soho (1573-1645), we also find the idea that the ego stands in the way of the detachment that characterises both Zen monk and samurai warrior (Haskel 2013). This type of Zen considers ethical concerns as ego-baggage barring the way to Buddhahood, and it is the type of Zen that, as we have seen, can be found everywhere in the pages of The Japanese Corpse.

Deleted: idea
Deleted: , anywhere,
Deleted: thus is fundamentally amoral
Commented [AS2]: The logic in this statement is unclear.
Durely this just makes it universal rather than amoral?
Deleted: the equation
Deleted: as the
Deleted: commissaris' encounter with


VAN OVERMEIRE 12

\section{Japanese Women: Between Femme Fatale and Helpless Child}

I started this article by stating that The Japanese Corpse is a detective novel, and it is rewarding, at this point, to investigate what type of detective novel it is. Below, I will show that the Japanese Corpse displays a good number of characteristics of the hardboiled detective novel. These generic properties explain why, despite the novel's insistence on a Zen-inspired non-dual perspective on reality, the characterization of nonwhites and women in the novel is very different from the manner with which Van de Wetering portrays his three white male protagonists. The Japanese Corpse therefore becomes a case study of what David McMahan has called 'Buddhist Modernism,' as it contains a complex cultural negotiation between Buddhist notions and engrained western ideas about Japan. My description of the main characteristics of the hardboiled detective novel here are drawn from John Scaggs' Crime Fiction.

The moral ambiguity of the characters in The Japanese Corpse does not only fit the perspective of Buddhist emptiness, it also matches the moral ambiguity of both the world portrayed in the hardboiled detective novel, and the investigators pursuing the criminal. Whereas classic detective stories, the most famous example of which are no doubt those featuring Sherlock Holmes, usually end in the mending of society, hardboiled detective stories, famously those of Raymond Chandler and Dashiell Hammett, end with society much the same as before. At the same time, the detectives, too, are barely any better than the criminals they fight (Scaggs 2005, 55-84). Both these hardboiled characteristics are shown in The Japanese Corpse: as discussed above, De Gier does not really care about breaking the law or hanging around with criminals. At the same time, the conclusion of the novel indicates that Japanese society will remain as corrupt as before: Dorin assures us that if the daimyo had not killed himself, the latter and his cronies would wield their political influence to get out of jail (Van de Wetering 1977, 277-78).

As a hardboiled detective novel, The Japanese Corpse also replicates the American Frontier myth. For the classic hardboiled detective novel, the location for adventure was California (extending westwards from its literary predecessor, the Western), a location that also promised personal redemption and renewal. In Raymond Chandler's novels, for example, one frequently encounters characters that have 
abandoned their own selves and have become new people. This, however, is often just an act, and it is no wonder such novels often feature dramatic motifs: everyone is just playing a role (Scaggs 2005, 57-65). De Gier's discovery of his new self, and the way The Japanese Corpse stresses acting in the Kyoto adventures of both De Gier and the commissaris as well as the theatrical performance of the daimyo can all be seen as references to the classic hard-boiled detective novel.

If $f_{2}$ however, the Frontier, whether it be Kyoto or Los Angeles, is a place of selfdiscovery in the hardboiled detective novel, it is only such for white men. John Scaggs asserts that in Chandler's novels, black men are never treated as human, sometimes being referred to with the impersonal pronoun 'it.' Similarly, women are never more than a threat in these narratives, with the famous figure of the 'femme fatale' a representation of this, (Scaggs 2005, 75-77). Likewise, while the three policemen-protagonists and their opponents in The Japanese Corpse are well-rounded (with important examples being De Gier and the daimyo), female characters lack any depth whatsoever, and can be classified into two, non-exclusive, types that are based on nationality: Japanese women are prostitutes to be used for sexual favors or for other purposes, and Dutch women are undesirable obstacles. It is worth discussing this particular feature of the novel in some depth.

The first female character we encounter in the novel is immediately marked by Grijpstra as a sex worker. Joanne Andrews, a half-Japanese woman whose fiancé has just been murdered, is 'too good-looking perhaps, and a bit overdressed. A prostitute perhaps?' (Van de Wetering 1977, 2). Grijpstra's assessment turns out to be correct: as Joanne Andrews confesses later, in Japan she was a 'barmaid in a yakusa nightclub in Kobe,' a sex worker job (Van de Wetering 1977, 152).

It is Grijpstra who introduces the other type of woman in the novel by comparing his own Dutch wife unfavorably with the 'lascivious' Joanne Andrews:

He thought of his own wife and shook his head again. A pudding of flesh addicted to television and creamcakes, and bad-tempered if she could find the energy, which wasn't so often anymore. She was given to staring at him now, nasty stares out of small bloodshot eyes, sunken into the puffy gleaming blubber which covered her skull. $\mathrm{He}$ breathed deeply and forced the thought to go away. He could think of his wife when he was with her, which didn’t happen so much now. (Van de Wetering 1977, 15) 
Although De Gier's girlfriend might have provided us with a female character who is active, intelligent, and independent, as Van de Wetering's description of her suggests, at the beginning of The Japanese Corpse she is dead. Among the living in this novel, there is simply no female character that escapes this two-fold classification based on sexual appetite. Either she is sexually appealing and thus a prostitute to be used, or she is not and thus uninteresting or even disgusting.

Nowhere is this clearer than in the depiction of Yuiko, who despite the considerable role she plays in the narrative, never becomes more than a tool for De Gier to reach sexual satisfaction, to track down the daimyo, and to reach a vision of non-dual reality (cf. supra). It should not be a surprise then that Van de Wetering's casts the 'meeting of East and West,' usually understood as a cultural encounter and exchange of ideas, as the encounter between a white male and a Japanese prostitute. Commenting on Rudyard Kipling's verse 'East is East, and West is West, and never the twain shall meet,' the commissaris says: 'It's rubbish [...] Absolute rubbish. I don't think the twain have ever been apart' (Van de Wetering 1977, 165). He makes this statement exactly when De Gier departs for the Japanese brothel where he will meet Yuiko for the first time. Earlier, the commissaris had already been informed of the historical precedent of prostitutes easing the way for Dutch business on the island of Deshima, the historical trading post of the Dutch with Tokugawa Japan from the 1600s onwards. These prostitutes were called 'destroyers of walls,' leading the commissaris to observe: 'Yes, our forefathers must have had a good time on this island, far removed from their nagging Dutch wives and screaming children, and cuddled by specially selected high-class prostitutes, supplied by the Japanese government, free of charge. A most interesting setup' (Van de Wetering 1977, 142). This quotation strengthens the idea that Japanese women are sexual objects and Dutch women are obstacles.

Van de Wetering thus holds quite closely to the hardboiled idea of women as corrupting and sexual objects. However, whereas in hard-boiled detective novels (and in film noir, the type of film that has its roots in these novels) the femme fatale has a devious agency that has led some scholars to read this role as empowering (Kaplan 1998), no such agency is allowed the Japanese women encountered in The Japanese Corpse. No agency is allowed them at all, since they are passive pawns to be used by 
men. Grijpstra and De Gier's first discussion of Japanese tourists visiting Amsterdam reflects this perspective:

I've seen them in town. They march around, like mechanical men, and they all have leather cross-straps, camera on the left, light meter on the right. Gray slacks, blue blazers. But the women seem very nice, especially when they are dressed in kimonos. They shuffle. Very dainty women. (Van de Wetering 1977, 7)

De Gier is speaking here, and one might see this speech as a representation of his narrow interests in womanizing. It is hard, nevertheless, to miss the stereotype of the Japanese tourist combined with that of the submissive geisha, stereotypes that continue to influence popular understandings of Japan today. Moreover, De Gier is not the only one who thinks this way: having arrived in Japan, the commissaris repeats the robotstereotype and adds another one, characterizing the Japanese looking at Mt. Fuji as children (Van de Wetering 1977, 103).

These racially charged stereotypes of the Japanese women as geisha/prostitutes and Japanese in general as robots and children show that, in addition to reproducing the racist stereotypes of the hardboiled novel, The Japanese Corpse also is the product of the Cold War cultural relationship between the United States and Japan. As Naoko Shibusawa has indicated, the image of the Japanese as geisha and child is intimately connected to Japan's post-war political relationship to the United States (Shibusawa 2006). In The Japanese Corpse, though, this image mixes with the masculine image of the devoted and honorable samurai, from whose enlightened and indifferent Zen perspective all distinctions disappear.

\section{Conclusion: The Japanese Corpse as case of Buddhist Modernism}

In its combination of hard-boiled genre conventions with references to Zen Buddhism as an amoral and non-dual worldview, The Japanese Corpse is a case of what David McMahan has called 'Buddhist modernism,' which he has explained as follows:

By 'Buddhist modernism' I do not mean all Buddhism that happens to exist in the modern era but, rather, forms of Buddhism that have emerged out of an engagement with the dominant cultural and intellectual forces of modernity. Buddhist modernism is a dynamic, complex, and plural set of historical 
processes with loose bonds and fuzzy boundaries. (McMahan 2008, 6) In his book, McMahan traces some of the 'features' and 'aspects' of Buddhist modernism, consistently noting that the 'adaptation' of Buddhism 'involves a reconfiguration of both tradition and context through contestation and negotiation as much as enthusiastic embrace. In many places where Buddhism has become a significant presence, it has been introduced and adapted in highly specific ways' (McMahan 2008, 19). For McMahan, then, Buddhist modernism is not a 'monolithic' entity, but a multifaceted phenomenon (McMahan 2008, 149).

In adapting the stereotypes of Cold War rhetoric of Japan together with the morality and characterizations of the hard-boiled novel, while proposing a nondiscriminatory, morally indifferent way of life as 'Zen,' Van de Wetering has created his own unique Buddhist modernist novel. As Laura Harrington has recently proposed, the role of the Cold War in shaping both Buddhist modernism and the discipline of Buddhist Studies has thus far been underappreciated (Harrington 2017). I would argue that the case of the Buddhist detective novel provides a productive point of departure for such a reappraisal. While The Japanese Corpse portrays Zen as an amoral and non-dualist perspective on reality, it denies Japanese and Dutch women this spiritual liberation, and in doing so shows us the challenges as well as the possibilities of transnational Buddhist and detective literature. 


\section{Acknowledgements}

A previous version of this paper was presented at the Lunchtime conversation series at Duke University, April 12-13, 2017. I wish to thank Richard Jaffe for inviting me, and the Religion faculty and students of Duke for their comments and suggestions. I also wish to thank Page Dubois for suggesting the avenue of research that led to the present work.

This work was financially supported by the Research Foundation, Flanders under the form of a postdoctoral fellowship.

\section{Disclosure Statement}

Author reports no financial interests or benefits resulting from this research.

\section{Notes}

${ }^{1}$ Likely Van de Wetering's name for Daitoku-ji (大徳寺), the famous temple in Kyoto that is the subject of The Empty Mirror.

${ }^{2}$ Afterzen does not have this passage, although it also maintains the connection between Musashi and Zen by calling the former 'the great Japanese medieval hero who overcame his ego to turn into the best sword fighter in the land' (Van de Wetering 1999, 155).

\section{References}

Benesch, Oleg. 2014. Inventing the Way of the Samurai: Nationalism, Internationalism, and Bushidō in Modern Japan. First edition. The Past \& Present Book Series. Oxford: Oxford University Press.

Grijpstra \& de Gier. 2004. Crime, Drama, Thriller.

Harrington, Laura. 2017. "Cold War Karma: A Brief History of Buddhist Studies and the CIA, 1951-1967." In New Studies of Buddhism in the West. Boston.

Haskel, Peter. 2013. Sword of Zen: Master Takuan and His Writings on Immovable Wisdom and the Sword Taie. Honolulu: University of Hawai'i Press.

Hawtree, Christopher. 2008. "Obituary: Janwillem van de Wetering | Books | The Guardian." October 14, 2008 http://www.guardian.co.uk/books/2008/oct/14/netherlands.

Jauch, Thomas. 1999. Der Blonde Affe. Crime.

Kaplan, E. Ann. 1998. Women in Film Noir. London: Palgrave Macmillan.

McMahan, David L. 2008. The Making of Buddhist Modernism. New York: Oxford University Press.

Nilsson, Louise, David Damrosch, and Theo d'Haen. 2017. Crime Fiction as World Literature. New York: Bloomsbury Academic.

Scaggs, John. 2005. Crime Fiction. London: Routledge.

Shibusawa, Naoko. 2006. America's Geisha Ally: Reimagining the Japanese Enemy. Cambridge, Mass.: Harvard University Press. 
VAN OVERMEIRE 18

Snyder, Gary, and William Scott McLean. 1980. The Real Work: Interviews \& Talks, 1964-1979. New Directions Publishing.

Van de Wetering, Janwillem. 1971. De Lege Spiegel Ervaringen in Een Japans Zenklooster. Amsterdam: De Driehoek.

. 1974a. Het Dagende Niets. Amsterdam: De Driehoek.

. 1974b. The Empty Mirror; Experiences in a Japanese Zen Monastery. 1st American ed. Boston: Houghton Mifflin.

1975. A Glimpse of Nothingness: Experiences in an American Zen Community. 1st American ed. Boston: Houghton-Mifflin.

1977. The Japanese Corpse. Boston: Houghton Mifflin. 1999. Afterzen: Experiences of a Zen Student out on His Ear. New York: St. Martins Press.

2007. Zuivere leegte: ervaringen van een respectloze zenleerling. Rotterdam: Asoka.

Van Overmeire, Ben. 2016. "Inventing the Zen Buddhist Samurai: Yoshikawa Eiji’s Musashi and Japanese Modernity." The Journal of Popular Culture 49 (5): 112545.

Verstappen, Wim. 1979. Grijpstra \& De Gier. Crime, Thriller, Comedy. - 1987. De Ratelrat. Comedy, Crime.

Yoshikawa, Eiji. 1995. Musashi. Translated by Charles S. Terry. New edition. Tokyo: Kodansha International.

\section{Notes on Contributor}

Ben Van Overmeire is currently a postdoctoral fellow of the Research Foundation - Flanders at the Ghent Centre for Buddhist Studies, Ghent University. His research interests include twentiethcentury Zen Buddhist literature, spiritual autobiography, and utopian narrative.

- ORCiD: 0000-0002-8399-3065

- Twitter: @Zenmirrors

- Website: benvanovermeire.com

- Affiliation: Postdoctoral Fellow of the Research Foundation - Flanders at the Ghent Centre for Buddhist Studies, Ghent University

- Address: Ghent Centre for Buddhist Studies, Department of Languages and Cultures, Ghent University, Blandijnberg 2, B-9000 Ghent, Belgium.

- Phone: +32092643810

- E-mail: ben.van.overmeire@gmail.com 
HARDBOILED ZEN 19

Figure Captions (all images (C) Ben Van Overmeire)

1. The 1977 cover of The Japanese Corpse.

2. Van de Wetering's calligraphic writing of jin-gi in The Japanese Corpse 